\title{
Work Motivation, Culture, And Economic Development: Is Work Motivation Shaped By Its Socio-Economic Context?
}

Robert Klonoski, Mary Baldwin College, USA

\begin{abstract}
Cultural impacts on work motivation have been well-studied. While a number of authors have assessed the effect of scarcity versus affluence on work motivation, few researchers have considered whether both cultural and economic factors may be jointly shaping national characteristics of work motivation. A regression analysis based on economic and cultural indexes indicates that a national level of work motivation is strongly correlated with aspects of culture as well as economic development. While national income is not, itself, a strong predictor of work motivation, indicators which describe a nation's economic strength and stability are. The article concludes with suggestions for further research.
\end{abstract}

Keywords: Work Motivation; Economic Development; Cultural Characteristics; Cultural Dimensions

\section{BACKGROUND}<smiles>[C]1C=CCCC1</smiles>

ince the first publication of Weber's (1904-5) text on the Protestant Work Ethic, the relationship of an individual to his or her work was interpreted within the context of the social environment in which it occurred. Intrinsic motivation was characterized by the need to achieve, but something that was developed through a process of economic socialization (McClelland, 1961). Maslow described a universally applicable hierarchy of needs based on the assumption that "man is a continually wanting animal," that is, that there may never be a point at which people do not strive for something more than what they currently have (Maslow, 1943, p. 370). Expectancy theory (Vroom, 1995, original work published in 1964) describes the simple and direct relationship between a person's expectation that his or her actions will yield a desired result and his or her motivation to perform it. Lawler and Porter (1967) added that self-efficacy was also a predictor of motivation and performance and argued that job satisfaction was a result rather than a cause of performance. The concept that outcomes could be measured in terms of their exchange value was raised by Blau (1964), who contended that defined outcomes were the goal of economic exchanges, while less specific outcomes created social obligations.

The 1980's saw goal setting theories rise to prominence (Pinder, 1988). Expectancy theory had used the strength of the desire for a particular outcome and the likelihood of being successful in the effort as the calculus for determining motivation. Goal setting theory rested on this foundation, but added that "self-efficacy typically is not assessed in terms of attaining a single goal or performance level, but to a range of performance levels." (Latham, 2007, p. 65). In characterizing individual goal setting in this way, Latham focused on the self-efficacy of the individual -- which may be high or low for reasons unrelated to the specific task at hand. Both expectancy and goal setting theory, however, recognize that the formation of a prediction of the likelihood of an outcome is predicated not only on intrinsic ability, but also on external factors, such as the availability of time or resources needed to accomplish a particular task. Separately, Markus and Kitayama (2001) viewed the independent or interdependent interpretation of self as a hallmark of an individualistic versus a collectivist society.

Another line of research analyzed work motivation from a cultural perspective. Steers and Sanchez-Runde (2002) argued that a person's self-efficacy was also a function of socially instilled norms and values. They further posited that characteristics of the socio-economic environment, such as education, levels of prosperity and 
government regulation help to frame behavior and shape work motivation (2002, pp. 191-192). This position was also argued by Peterson and Ruiz-Quintanilla (2003) who related the character of a person's intrinsic work motivation to the nature of the government (i.e., flexible versus bureaucratic) under which they functioned. Erez (2008) added to the discussion in describing how culture shapes individual values and the relative importance and character of work-related goals.

While the early authors on this topic had focused on those things which defined the direct connection between a person and his or her work, later authors had begun to address non-work influences on work behavior. Kanfer, Chen and Pritchard described and distinguished three of these: (1) the content of a person's work, that is the "biological, cognitive, personality and affective systems [that] shape relatively stable individual differences in preferred actions, settings and strategies," (2) the context in which motivation is framed, that is, the nonwork factors that influence work motivation, and (3) the change associated with a person's environment (2008, pp. 9-11). Kossek and Misra (2008) examined the role of new communication technologies and how the increasingly mobile nature of a knowledge-based economy and workforce has given rise to discussions of work-life balance and work-life integration.

While researchers have paid increasing attention to the environments in which decisions about job and career choices are made and about the strength and shape of motivation in comparative cultural settings, these studies have largely treated the state of economic development of a society as a given. Inglehart (1997) distinguished between those countries whose economic environments can be characterized by scarcity and those that are more economically secure. His comment that "economic factors tend to play a decisive role under conditions of economic scarcity, but as scarcity diminishes, other factors shape society to an increasing degree" highlights the importance of economic development in determining why people are motivated to work $(1997$, p. 59). The argument was supported by Xu and van de Vliert's (2003) study of workers in three industries across 43 countries. In positing an explanation for the difference in the way workers in undeveloped versus industrialized countries view work, the authors state, "in countries with a well-developed social security system, workers may tend to place more emphasis on higher needs and are therefore more likely to be motivated by intrinsic rewards" (2003, p. 162). In both studies, economies were treated as either ones of scarcity or of security and nations as poor or rich, but this binary classification of economies may act to abbreviate the discussion of the impact of economic conditions on workers and work motivation. The purpose of this study is to investigate whether a country's cultural orientation along with its state of economic development affects the work motivation of its population.

\section{ECONOMIC DEVELOPMENT}

In his seminal work, "The Coming of Post-Industrial Society" Bell (1973) announced the dawning of an age that was to be distinguished from the industrial era that had preceded it. In his view, what distinguished the postindustrial era from the industrial one was the purpose for which the preponderance of labor was being employed (p. 127) and the level of education the average laborer had received (p. 143). Bell noted that in 1956, the number of "white collar" workers in the United States exceeded the number of "blue collar" workers, harkening in an age of science and technology as well as work centricity (1973, p. 127). A decade later, Huber (1984, p. 931) furthered post-industrial theory by marking the advanced pursuit of knowledge as one of the hallmarks of this new age. Both Bell and Huber had recognized that education was a critical part of the new economy. Bell adopted the number of years of formal education as his determinative metric while Huber focused on the percentage of the working population that had received some education at the tertiary level.

The salient features of an agrarian economy have also been defined in terms of their labor and educational characteristics. Rosell identified the presence of attached labor, or labor with long term contracts tying them to a specific employer or farm owner for the duration of a harvest cycle (2007, pp. 79-80). This assessment is reinforced by Jayachandran, whose study of workers in rural India found that the inability of farm workers to shift jobs in times of labor oversupply added to wage volatility (2004, pp. 3-4). Reddi's comprehensive comparative of the growth of the South Korean and Indian economies highlighted certain national labor and education metrics as marking an undeveloped economy (2003, pp. 9-19). An undeveloped country will typically show a lower level of agricultural productivity per laborer and per acre farmed than an advanced country. Farms in undeveloped countries are smaller and use less technology than those in more developed countries and so are unable to realize economies of scale or 
the benefits of process efficiencies common to more developed nations. Second, Reddi notes that the development of an educational system differentiates the agrarian and industrial communities, something that stems from a need to upgrade a labor force to a level required to meet industrial level needs (2003, p. 19).

A comprehensive assessment of the characteristics of economic development is provided by the World Economic Forum in the Global Competitiveness Report (2010-2011). The authors base their assessment on twelve sets of indicators of national performance which are grouped for assessing three different types of economies: For factor-driven economies, institutions, infrastructure, macroeconomic environment, and health and primary education; for efficiency-driven economies, higher education and training, goods market efficiency, labor market efficiency, financial market development, technological readiness, market size; and for innovation-driven economies, business sophistication and innovation.

The variation in national income, along with the levels of stability and breadth of job markets may, along with cultural dimensions, impact the way in which people view the nature and importance of work. A person's concept of the value of work may be shaped, in part, by the nature and kinds of economic opportunities that are available to workers at a given time and in a given nation. The question asked here is: Is work motivation (measured at the national level) related to the cultural dimensions as well as to the state of economic development of a county?

\section{METHODOLOGY}

The analysis drew from three databases: One, economic data were derived from the CIA World Factbook, which provides common-basis metrics for national economies. Two, cultural data were measured using Hofstede's cultural dimensions, something which he has generously shared online. Three, attitude toward work and work motivation metrics were taken from the World Values Survey, for which the data is also freely available online. (Score calculations for work motivation metrics are detailed in Appendix A.)

The economic metrics selected for the analysis were: "gross domestic product per capita" as an indicator of economic development and prosperity, "life expectancy" and "infant mortality rates" as indicators of economic development and stability, and "median age" of the population, a metric derived from Inglehart's (2007) contention that economic prosperity is correlated with the health and well-being of a population. The last three metrics are indicators of the overall economic stability of a country and address the degree of development and durability of its economic infrastructure. The social metrics used for this analysis are those used by Hofstede, Hofstede and Minkov (2010) in their analysis of cultural dimensions, namely, power distance, masculinity/femininity, uncertainty avoidance, and individualism versus collectivism. The World Values Survey, which is a database of attitudinal surveys collected at the national level in more than 50 countries, contains six questions that focus on attitude towards work (detailed in Appendix B). Regression analyses were run using economic and social metrics as a predictor of each of the six work attitude measures.

\section{RESULTS}

Responses to four of the six questions in the World Values Survey that address work motivation are highly correlated with unique combinations of economic and cultural indexes; responses to the other two questions are also correlated with economic and cultural indexes, but with a medium effect size. The combinations of the variables yielding the highest values for adjusted $\mathrm{r}^{2}$ are listed in the Table 1 .

As the years of school, GDP/Capita, median age and life expectancy increase, the measured levels of work motivation decrease. As the infant mortality rate increases, the measured level of work motivation increases. When run individually, uncertainty avoidance and masculinity were not correlated with any of the indicators of the level of work motivation; however, individualism was negatively associated with work motivation while power distance was positively associated with it. 
Table 1

\begin{tabular}{|c|c|c|c|}
\hline Questions & $\mathbf{r}^{2}$ & $\underset{\mathbf{r}^{2}}{\text { Adjusted }}$ & Indexes \\
\hline 1. How important is work in your life? & $.764 * * *$ & .665 & $\begin{array}{l}\text { Infant Mortality, Individualism, Masculinity, } \\
\text { Uncertainty Avoidance, Long Term Orientation }\end{array}$ \\
\hline $\begin{array}{l}\text { 2. In order to develop talents, you need } \\
\text { to have a job. (Agree/Disagree) }\end{array}$ & $.900 * * *$ & .800 & $\begin{array}{l}\text { Life expectancy, GDP/Capita, Power Distance, } \\
\text { Individualism, Long Term Orientation, Median } \\
\text { Age }\end{array}$ \\
\hline $\begin{array}{l}\text { 3. People who don't work turn lazy. } \\
\text { (Agree/Disagree) }\end{array}$ & $.887 * * *$ & .807 & $\begin{array}{l}\text { Median Age, Individualism, Masculinity, Long } \\
\text { Term Orientation, GDP/Capita }\end{array}$ \\
\hline $\begin{array}{l}\text { 4. Work comes first, even if it means } \\
\text { less spare time. (Agree/Disagree) }\end{array}$ & $.967 * * *$ & .934 & $\begin{array}{l}\text { Median Age, Infant Mortality, Life Expectancy, } \\
\text { Individualism, Uncertainty Avoidance, Long } \\
\text { Term Orientation }\end{array}$ \\
\hline $\begin{array}{l}\text { 5. It is humiliating to receive money } \\
\text { without having to work for it. } \\
\text { (Agree/Disagree) }\end{array}$ & $.809 * * *$ & .724 & $\begin{array}{l}\text { Median Age, Individualism, Masculinity, Long } \\
\text { Term Orientation }\end{array}$ \\
\hline $\begin{array}{ll}\text { 6. Work is a duty to society } \\
\text { (Agree/Disagree) }\end{array}$ & $.777 * * *$ & .638 & $\begin{array}{l}\text { GDP/Capita, Years in School, Individualism, } \\
\text { Long Term Orientation, Median Age }\end{array}$ \\
\hline
\end{tabular}

\section{ANALYSIS \& LIMITATIONS}

The importance of work in a person's life is best predicted by a mix of cultural and economic indexes, something that gives credence to the argument that people view work as fulfilling both an economic and a social role.

The six questions could be characterized as having a basis in culture or in economics. For example, the question of whether or not a person who does not work might become lazy or whether it would be humiliating to receive money without having worked for it are both based in cultural ethics. On the other hand, the question concerning putting work ahead of leisure time asks whether economic or social activity is a priority. The phrasing of the question suggests the basis on which they are answered.

Of the economic indicators, median age contributed to the calculation more frequently than did GDP/Capita. Median age is often used as an indicator of the wealth and stability of a country (Inglehart, 2007). One explanation for this may be that it is the state of economic development of a country more so than the level of current income that affects work motivation. While the two measures are correlated, median age is a measure that implies that a country's health systems are developed and effective, that people have longevity and that the economic environment has been relatively stable over time. GDP/Capita focuses only on current earnings.

Of the cultural indicators, individualism and long term orientation were the most frequently cited appearing in all six of the regression equations. Much literature has been dedicated to understanding the implications of individualist versus collectivist views of the role of the worker in an organization or in his or her perception of self (Markus and Kitayama, 1991), but these studies do not address the absolute level of work motivation. Research by Elizur, Borg, Hunt and Beck (1991) demonstrated the high value placed on achievement in China, Taiwan, Korea and Israel - all countries scoring highly in terms of collectivism. The above regression equations each associate higher levels of individualism with lower levels of work motivation.

Long term orientation is more highly correlated with collectivist cultures than with individualist ones. Although the concept has long been associated with the Protestant Work Ethic (Furnham, 2001), it is not exclusively a Western concept (see: Munroe \& Munroe, 1986; Niles, 1999; Uygur, 2009; Sharma \& Mohapatra, 2009). Hofstede (n.d.) ranks China and Hong Kong among the highest scoring nations on this metric, and Norway, Canada and Great Britain among the lowest.

The most surprising result of the study was the linearity of the function and the degree to which work motivation, especially that measuring work as a priority versus leisure, were predictable by a combination of cultural and economic factors. 
The methodology has several limitations: First, data was selected at the country level of analysis. This is a limitation of the study in that cultures and economies are seldom homogenous within a nation's borders. As Bandura argued, "cultures are no longer insular" and globalization may work to erode certain aspects of culture that result in organizational ineffectiveness or inefficiency (2002, p. 283). Further, Gelfand, Nishii, and Raver studied the degree of "cultural tightness-looseness" in characterizing the degree to which adherence to cultural norms is expected within a society and found that immigration patterns and exposure to international trade act to promote tolerance of diversity (2006, p. 1226). This being said, the economic and cultural studies on which global comparative evaluations are made often select the country as the level of analysis because of the availability of data at this level and because nations generally provide a stronger point of identification and focus for loyalty than other geographical clusters.

Second, Ailon (2008) examined Hofstede's classifications and identified embedded Western value orientations, highlighting the difficulty of preparing a cross-cultural research study that is itself free of the cultural biases of the author. While Ailon's critique may have demonstrated a limitation of the work, Hofstede's study has nonetheless formed the basis of much cross-cultural research, and the dimensions he described have formed the basis of further work by House, Quigley and de Luque (2010), and Trompenaars and Turner (1997). The concept of individualism versus collectivism was also paralleled by Markus and Kitayama (1991) in their description of the independent and interdependent construal of self.

\section{CONCLUSION}

Work motivation is shaped by both cultural and economic circumstances. While dimensions such as uncertainty avoidance and power distance are positively correlated with work motivation, economic indicators that point to increasingly developed and stable economies may be correlated with reduced levels of work motivation. Measured separately, economic as well as cultural indexes can predict levels of work motivation with a low to medium effect size; however, when assessed together a more complete picture of work motivation may be drawn.

Further research is needed to identify the unique characteristics of work motivation within the various combinations of economic development and cultural orientation. By doing so, managers may be able to develop a more complete picture of the intrinsic and extrinsic motivators that pertain to workers in developing and developed countries around the globe.

\section{AUTHOR INFORMATION}

Robert Klonoski is an Assistant Professor of Business Administration at Mary Baldwin College in Virginia, USA. His research interests include educational technologies and work motivation. He has also taught at the University of the District of Columbia, the University of Virginia and has worked in the financial services industry. Professor Klonoski holds a B.S. in Finance from Fairfield University, an M.B.A. from the University of Connecticut, and a J.D. from Brooklyn Law School. He is currently completing his Doctorate in Management at the University of Maryland, University College. E-mail: rklonosk@mbc.edu

\section{REFERENCES}

1. Ailon, G. (2008). Mirror, mirror on the wall: Culture's consequences in a value test of its own design. Academy of Management Review, 33(4), 885-904. Downloaded from: http://www.aomonline.org

2. Bandura, A. (2002). Social cognitive theory in cultural context. Applied Psychology: An International Review, 51(2), 269-290. Downloaded from: http:// www.iaapsy.org

3. Bell, D. (1973). The Coming of Post-Industrial Society: A Venture in Social Forecasting. New York: Basic Books.

4. $\quad$ Blau, P. (1964). Exchange and power in social life. New York: Wiley.

5. Central Intelligence Agency (2010). The CIA world factbook, 2011. New York, NY: Skyhorse Publishing.

6. Elizur, D., Borg, I., Hunt, R., \& Beck, I. (1991). The structure of work values: A cross-cultural comparison. Journal of Organizational Behavior 12(1), 21-38. doi: 10.1002/job.4030120103 
7. Erez, M. (2008). Social-Cultural Influences on Work Motivation. In R. Kanfer, G. Chen \& R. Pritchard (Eds.), Work motivation: Past, present, and future (pp. 501-538). New York, NY: Routledge.

8. Furnham, A. (2001). The Protestant work ethic: The psychology of work-related beliefs and behaviors. New York, NY: Routledge.

9. Gelfand, M. J., Nishii, L. H., \& Raver, J. L. (2006). On the nature and importance of cultural tightnesslooseness. Journal of Applied Psychology, 91(6), 1225-1244. doi:10.1037/0021-9010.91.6.1225

10. Hofstede, G., Hofstede, G. J., \& Minkov, M. (2010). Cultures and organizations: Software of the mind. New York, NY: McGraw Hill.

11. Hofstede, G. (n.d.) Geert Hofstede ${ }^{\mathrm{tm}}$ cultural dimensions. Retrieved from: http://www.geerthofstede.com/hofstede dimensions.php

12. House, R. J., Quigley, N. R., \& de Luque, M. (2010). Insights from Project GLOBE. International Journal of Advertising, 29(1), 111-139. Downloaded from: http:// www.internationaljournalofadvertising.com

13. Huber, G. (1984). The nature and design of post-industrial organizations. Management Science, 30(8), 928-952. Downloaded from: http://mansci.journal.informs.org/

14. Inglehart, R. (1997). Modernization and postmodernization: Cultural, economic and political changes in 43 societies. Princeton, NJ: Princeton University Press.

15. Jayachandran, S. (2004). Essays in development economics and political economy. (Ph.D. dissertation). Downloaded from: Dissertations \& Theses: Full Text. (Publication No. AAT 3131874).

16. Kanfer, R., Chen, G., \& Pritchard, R. D. (2008). The three C's of work motivation: Content, context, and change. In R. Kanfer, G. Chen, R. D. Pritchard, R. Kanfer, G. Chen, R. D. Pritchard (Eds.), Work motivation: Past, present, and future (pp. 1-16). New York, NY: Routledge/Taylor \& Francis Group.

17. Kossek, E. \& Misra, K. (2008). Nonwork influences on work motivation. In R. Kanfer, G. Chen, R. D. Pritchard, R. Kanfer, G. Chen, R. D. Pritchard (Eds.), Work motivation: Past, present, and future (pp. 471499). New York, NY: Routledge/Taylor \& Francis Group.

18. Latham, G. (2007). Work motivation: History, theory, research, and practice. Thousand Oaks, CA: Sage Publications.

19. Lawler III, E., \& Porter, L. (1967). The effect of performance on job satisfaction. Industrial Relations, 7(1), 20-28. Downloaded from http://www.irle.berkeley.edu/indrel/

20. Pinder, C. C. (1998). Work motivation: Theory, issues, and applications. Upper Saddle River, NJ: Prentice Hall.

21. Markus, H. R., \& Kitayama, S. (1991). Culture and the self: Implications for cognition, emotion, and motivation. Psychological Review, 98(2), 224-253. doi:10.1037/0033-295X.98.2.224

22. Maslow, A. (1943). A theory of human motivation. Psychological Review, 50(4), 370-396. doi: $10.1037 / \mathrm{h} 0054346$

23. McClelland, D. (1961). The achieving society. Princeton, NJ: Van Nostrand.

24. Munroe, R. \& Munroe, R. (1986). Weber's Protestant ethic revisited: An African case. Journal of Psychology, Interdisciplinary and Applied 120(5), 447-455. Downloaded from: http://heldref.metapress.com/app/home/journal.asp?referrer=parent\&backto=browsepublicationsresults,31, 48;

25. Niles, F.S. (1999). Toward a Cross-Cultural Understanding of Work-Related Beliefs. Human Relations, 52(7), 855-867. Downloaded from: http://www.tavinstitute.org/humanrelations/about_journal/aims.html

26. Peterson, M. F., \& Ruiz-Quintanilla, S. (2003). Cultural socialization as a source of intrinsic work motivation. Group \& Organization Management, 28(2), 188-216. doi:10.1177/1059601103251228

27. Reddi, V. (2003). The growth experience of India and South Korea: An empirical study. (Ph.D. dissertation). Downloaded from: Dissertations \& Theses: Full Text. (Publication No. AAT 3083155).

28. Rosell, C. (2007). Essays in the economics of technology and innovation, and development economics. (Ph.D. dissertation). Downloaded from Dissertations \& Theses: Full Text. (Publication No. AAT NR27693).

29. Sharma, B., \& Mohapatra, M. (2009). Personal \& Situational Factors as Predictors of Managerial Motivation. The Indian Journal of Industrial Relations, 44(3), 426-440. Downloaded from: http://srcirhr.com/ijir.php

30. Steers, R. \& Sanchez-Runde, C. (2002). Culture, motivation, and work behavior. In M. Gannon \& K. Newman (Eds.), The Blackwell handbook of principles of cross-cultural management (pp. 190-216). Bodmin, UK: MPG Books. 
31. Trompenaars, F. \& Turner, C.H. (1998). Riding the waves of culture: Understanding diversity in global business, $2^{\text {nd }}$ ed. New York, NY: McGraw Hill

32. Uygur, S. (2009) The Islamic work ethic and the emergence of Turkish SME owner-managers. Journal of Business Ethics, 88, 211-225. doi:10.1007/s10551-009-0107-z

33. Vroom, V. (1995). Work and motivation. San Francisco, CA: Jossey-Bass (Original work published 1964).

34. Weber, M. (2009). The protestant work ethic and the spirit of capitalism. Casper, WY: Information Age Publishing, Inc. (Original work published 1904-5).

35. World Economic Forum (2010-2011). Global competitiveness report. Retrieved from: http://www.weforum.org/reports

36. World Values Survey (2005). Official data file v.20090901, 2009. World Values Survey Association www.worldvaluessurvey.org.

37. Xu, H., \& van de Vliert, E. (2003). Where intrinsic job satisfaction fails to work: national moderators of intrinsic motivation. Journal of Organizational Behavior, 24(2), 159. doi:10.1002/job.186 
Appendix A: Economic Competitiveness and Attitude towards Work, Science and Technology

\begin{tabular}{|c|c|c|c|c|c|c|}
\hline \multicolumn{7}{|c|}{ World Values Survey Indexes } \\
\hline Country & $\begin{array}{c}\text { Importance in } \\
\text { Life: Work }\end{array}$ & $\begin{array}{l}\text { Humiliating to } \\
\text { receive money } \\
\text { without work }\end{array}$ & $\begin{array}{l}\text { Work is a duty } \\
\text { to society }\end{array}$ & $\begin{array}{l}\text { Work comes } \\
\text { first }\end{array}$ & $\begin{array}{c}\text { Non-workers } \\
\text { turn lazy }\end{array}$ & $\begin{array}{l}\text { Work needed to } \\
\text { dev. talents }\end{array}$ \\
\hline Italy & 3.574 & 3.585 & 3.803 & 3.338 & 3.862 & 3.654 \\
\hline Spain & 3.349 & 3.317 & 3.700 & 3.233 & 3.609 & 3.508 \\
\hline U.S.A. & 3.060 & 3.240 & 3.513 & 2.857 & 3.502 & 3.254 \\
\hline Canada & 3.305 & 3.195 & 3.639 & 2.847 & 3.335 & 3.242 \\
\hline Japan & 3.359 & 3.364 & 3.726 & 2.748 & 3.875 & 3.752 \\
\hline Mexico & 3.831 & 3.256 & 3.953 & 3.302 & 3.821 & 4.907 \\
\hline South Africa & 3.693 & 3.467 & 3.903 & 3.946 & 3.546 & 4.069 \\
\hline Australia & 3.135 & 3.315 & 3.503 & 2.361 & 3.541 & 3.389 \\
\hline Norway & 3.428 & 3.359 & 4.082 & 3.179 & 3.379 & 3.629 \\
\hline Sweden & 3.413 & 2.877 & 3.537 & 2.891 & 2.981 & 3.113 \\
\hline Argentina & 3.663 & 3.922 & 4.037 & 4.077 & 4.010 & 4.302 \\
\hline Finland & 3.271 & 3.114 & 3.634 & 2.919 & 3.551 & 3.423 \\
\hline South Korea & 3.510 & 3.634 & 3.690 & 3.100 & 4.309 & 4.386 \\
\hline Poland & 3.447 & 3.576 & 3.777 & 3.554 & 3.959 & 4.274 \\
\hline Switzerland & 3.440 & 3.206 & 3.734 & 3.196 & 3.378 & 3.921 \\
\hline Brazil & 3.638 & 3.496 & 3.872 & 3.605 & 3.832 & 3.773 \\
\hline Chile & 3.522 & 3.495 & 4.007 & 3.579 & 3.993 & 4.008 \\
\hline India & 3.617 & 4.074 & 3.996 & 3.948 & 4.090 & 3.980 \\
\hline Slovenia & 3.371 & 3.911 & 3.598 & 3.818 & 3.942 & 4.183 \\
\hline Romania & 3.391 & 3.739 & 3.964 & 4.058 & 4.301 & 4.238 \\
\hline China & 3.321 & 3.727 & 3.923 & 3.795 & 3.952 & 4.021 \\
\hline Taiwan & 3.489 & $\mathrm{n} / \mathrm{a}$ & $\mathrm{n} / \mathrm{a}$ & $\mathrm{n} / \mathrm{a}$ & $\mathrm{n} / \mathrm{a}$ & $\mathrm{n} / \mathrm{a}$ \\
\hline Turkey & 3.382 & 4.268 & 4.210 & 3.777 & 4.300 & 4.203 \\
\hline Ukraine & 3.103 & 3.495 & 3.467 & 3.139 & 3.957 & 3.971 \\
\hline Russia & 3.253 & $\mathrm{n} / \mathrm{a}$ & $\mathrm{n} / \mathrm{a}$ & $\mathrm{n} / \mathrm{a}$ & $\mathrm{n} / \mathrm{a}$ & $\mathrm{n} / \mathrm{a}$ \\
\hline Peru & 3.658 & 3.572 & 3.952 & 3.791 & 3.875 & 3.728 \\
\hline Uruguay & 3.630 & 3.465 & 3.794 & 3.530 & 3.607 & 3.638 \\
\hline Ghana & 3.924 & 3.338 & 4.462 & 4.218 & 4.152 & 4.009 \\
\hline Moldova & 3.321 & 3.469 & 3.353 & 3.412 & 3.826 & 3.812 \\
\hline Georgia & 3.665 & 3.628 & 3.920 & 4.152 & 4.076 & 4.210 \\
\hline Thailand & 3.469 & 3.689 & 4.084 & 4.064 & 3.917 & 4.075 \\
\hline Indonesia & 3.836 & 3.845 & 3.491 & 3.997 & 4.022 & 3.954 \\
\hline Viet Nam & 3.295 & 4.148 & 4.324 & 3.909 & 4.207 & 4.293 \\
\hline Serbia & 3.498 & 3.507 & 3.414 & 3.51 & 3.686 & 3.653 \\
\hline New Zealand & 3.200 & $\mathrm{n} / \mathrm{a}$ & $\mathrm{n} / \mathrm{a}$ & $\mathrm{n} / \mathrm{a}$ & $\mathrm{n} / \mathrm{a}$ & $\mathrm{n} / \mathrm{a}$ \\
\hline Egypt & 3.448 & 4.263 & 4.582 & 4.566 & 4.448 & 4.013 \\
\hline Morocco & 3.820 & 3.994 & 4.344 & 4.260 & 3.933 & 4.353 \\
\hline Iran & 3.688 & $\mathrm{n} / \mathrm{a}$ & $\mathrm{n} / \mathrm{a}$ & $\mathrm{n} / \mathrm{a}$ & $\mathrm{n} / \mathrm{a}$ & $\mathrm{n} / \mathrm{a}$ \\
\hline Jordan & 3.489 & 3.194 & 4.598 & 4.368 & 4.416 & 4.336 \\
\hline Cyprus & 3.408 & 3.674 & 3.876 & 3.536 & 3.940 & 3.778 \\
\hline Iraq & 3.771 & $\mathrm{n} / \mathrm{a}$ & $\mathrm{n} / \mathrm{a}$ & $\mathrm{n} / \mathrm{a}$ & $\mathrm{n} / \mathrm{a}$ & $\mathrm{n} / \mathrm{a}$ \\
\hline Guatemala & 3.942 & 3.523 & 4.269 & 3.994 & 4.112 & 4.156 \\
\hline Hong Kong & 3.061 & 3.123 & 3.821 & $\mathrm{n} / \mathrm{a}$ & $\mathrm{n} / \mathrm{a}$ & $\mathrm{n} / \mathrm{a}$ \\
\hline Trinidad \& Tobago & 3.755 & 3.149 & 4.110 & 3.775 & 3.996 & 3.427 \\
\hline Andorra & 3.395 & 3.055 & 3.213 & 2.512 & 2.503 & 3.643 \\
\hline Malaysia & 3.629 & 3.798 & 3.962 & 3.888 & 3.982 & 4.098 \\
\hline Burkina Faso & 3.885 & 3.540 & 4.366 & 3.903 & 3.911 & 4.401 \\
\hline Ethiopia & 3.868 & 4.197 & 4.364 & 4.366 & 4.261 & 4.222 \\
\hline Mali & 3.859 & 3.878 & 4.515 & 4.336 & 4.276 & 4.570 \\
\hline Rwanda & 3.630 & 3.717 & 4.462 & 4.387 & 4.456 & 4.201 \\
\hline Zambia & 3.712 & 3.266 & 3.904 & 3.720 & 3.704 & 3.325 \\
\hline Germany & 3.309 & 3.124 & 3.748 & 3.640 & 3.303 & 4.014 \\
\hline
\end{tabular}

The indexes were calculated by weighting the survey responses. For a Likert scale rating running from "Strongly Disagree" to "Strongly Agree", an answer of "Strongly Disagree" was assigned a value of 1, "Disagree" a value of 2, "Neutral" a value of 3, "Agree" a value of 4, and "Strongly Agree" a value of 5. The World Values Survey responses were recorded by the percentage of people responding to one of the points on the scale. The index is the additive value of the percentage of respondents answering "Strongly Disagree" times the point value of 1, plus the percentage of respondents answering "Disagree" times the point value of 2 , etc. 


\section{Appendix B: World Values Survey Questions on Work and Work Motivation}

There are six questions in the World Values Survey that focus on work and work motivation, namely:

All respondents were asked:

V4A - Please say, for each of the following, how important it is in your life: Work Answers: $\quad$ Very important

Quite important

Not very important

Not at all important

Don't know

Working respondents were asked:

V50 - Do you agree or disagree with the following statements: To develop talents, you need to have a job.

Answers:

Strongly agree

Agree

Neither agree nor disagree

Disagree

Strongly disagree

Don't know / No answer / Not applicable / Not asked / Missing or unknown

V51 - Do you agree or disagree with the following statements: It is humiliating to receive money without having to work for it.

Answers: $\quad$ Strongly agree

Agree

Neither agree nor disagree

Disagree

Strongly disagree

Don't know / No answer / Not applicable / Not asked / Missing or unknown

V52 - Do you agree or disagree with the following statements: People who don't work turn lazy.

Answers: $\quad$ Strongly agree

Agree

Neither agree nor disagree

Disagree

Strongly disagree

Don't know / No answer / Not applicable / Not asked / Missing or unknown

V53 - Do you agree or disagree with the following statements: Work is a duty towards society.

Answers:

Strongly agree

Agree

Neither agree nor disagree

Disagree

Strongly disagree

Don't know / No answer / Not applicable / Not asked / Missing or unknown

V54 - Do you agree or disagree with the following statements: Work should come first even if it means less spare time.

Answers:

Strongly agree

Agree

Neither agree nor disagree

Disagree

Strongly disagree

Don't know / No answer / Not applicable / Not asked / Missing or unknown 
International Journal of Management \& Information Systems - Fourth Quarter $2011 \quad$ Volume 15, Number 4 NOTES 